\title{
Age-Related Differences in Sentence Processing of Who-Questions: An Eye-Tracking Study
}

\author{
Ji-Hye Jang, Jee Eun Sung \\ Department of Communication Disorders, Ewha Womans University, Seoul, Korea
}

Correspondence: Jee Eun Sung, PhD Department of Communication Disorders, Ewha Womans University, 52 Ewhayeodae-gil, Seodamun-gu, Seoul 03760, Korea

Tel: $+82-2-3277-2208$

Fax: +82-2-3277-2122

E-mail: jeesung@ewha.ac.kr

Received: January 3, 2020

Revised: February 1, 2020

Accepted: February 11,2020

This work was supported by the Ministry of Education of the Republic of Korea and the National Research Foundation of Korea (NRF2019R1A2C1089280).

\begin{abstract}
Objectives: The purpose of this study was to compare the performance and eye tracking data of the young and the old in sentence processing tasks using the 'who+nominative' and 'who+accusative'. Methods: Participants in this study were 21 normal young adults and 17 normal elderly adults. All subjects passed the screening test for cognition and language, and there was no difference in education between the groups. Pictures and stories were presented at the same time, then subjects were asked to choose the corresponding answer on the screen. Results: First, the accuracy of the elderly group was significantly lower than that of young group. The elderly group performed much lower in the type'who +accusative.' Second, there was no significant difference between the groups in fixation duration for the target stimulus, but all groups had lower fixation duration in the type of 'who+accusative'. Also, the heat map shows that fixation of the elderly was more dispersed than the young group. Finally, the fixation proportion of the target stimulus according to the time interval showed that the fixation proportion of the elderly decreased in the last section of the sentence. Conclusion: The elderly group showed lower accuracy and stronger gaze dispersion in 'who+accusative' type than the young group. Furthermore, the lower rate of fixation proportion for the elderly in the last section of the sentence is due to the lower efficiency of the sentence integration process compared to the young.
\end{abstract}

Keywords: Sentence processing, Eye-tracking study, Case marker, Who-questions, Aging
노화는 신체 전반에 변화를 불러 일으켜 인간의 기본적인 능력 에 부정적 영향을 끼친다. 그 중에서도 노화는 인간의 언어 및 인지 능력에 상당한 영향을 미친다(Kim \& Oh, 2013). 예를 들어, 노화에 따라 노년층의 수용 및 표현 언어 능력이 청년층에 비해 저하되는 경향을 보인다(Thornton \& Light, 2006). 또한, 구문 분석 및 해석 능력 역시 노화에 따라 감소할 수 있고 이것은 작업기억과 같은 인 지능력 및 인지처리와 연관되는 것으로 알려져 있다(Caplan, Dede, Waters, Michaud, \& Tripodis, 2011). 그 중 작업기억 용량이론(working memory capacity theory)에 따르면, 통사적으로 복잡한 문장 의 경우에 더 많은 작업기억 용량이 요구되고, 개인의 제한된 작업 기업 용량에 기인하여 통사적 복잡성이 증가할수록 과제 수행력이 저하되는 것으로 보고된다(Just \& Carpenter, 1992; Kemper \& Kemtes, 1999). 문장처리에 있어서 의미적 처리와 통사적 처리가 중요 한 부분임을 미뤼볼 때, 노화에 따른 인지처리능력 저하가 구문분
석 및 의미해석능력 손상과 부적 상관관계가 있다는 다양한 연구들 은 매우 중요한 의미를 가지며(Caplan et al., 2011; Kemper, Thompson \& Marquis, 2001), 노화 및 인지처리와 관련된 문장이해능력 손상에 관한 연구는 다양한 통사적 구조를 활용하여 연구되고 있 다(Just \& Carpenter, 1992; Kemper \& Kemtes, 1999; Caplan et al., 2011). 본 연구에서는 문장처리의 다양한 측면 중에서도 의문사 처 리와 관련된 노화에 따른 영향을 살펴보고자 한다.

우리는 대화를 통해 상대방과 소통하는데, 그 대화속에서 질문 을 이용하여 정보를 주고받으며 의사를 전달할 수 있다. 이렇듯 질 문은 우리 대화에서 흔히 나타나는 기능이고 질문의 유형에서 가 장 빈번하게 사용되는 문법적 지표가 '의문사'이다. 한국어의 대표 적인 의문사로는 '누구(Who)'가 있으며, '누구’의 경우 격조사와 결 합하여 문장에서 격을 취하게 된다. 즉, '누구'와 '가'라는 주격 조사 와 결합된 형태인 '누가'의 경우, 문장 내에서 주격에 해당하는 내 
용을 질문하는 의문사의 역할을 하며, '를'이라는 목적격 조사와 결 합한 형태인 ‘누구를'의 경우 목적격 내용을 물어보는 문법적 지표 로 구현된다(National Institute of Korean Language, 2010). 누구 (who) 의문사의 출현을 살펴보면, '누구(who)+가'의 형태가 '누구 (who)+를'의 형태보다 그 능력이 먼저 발달하는 것으로 보고된다 (Tyack \& Ingram, 1977; Kim, 1997). 격조사가 한국어 처리에서 매 우 중요한 역할을 하는 문법적 지표임을 감안할 때, 동일한 '누구 (who)' 의문사임에도 불구하고 그 뒤에 결합하는 격조사의 종류에 따라 문장 처리에 영향을 줄수 있다는 측면을 주목할 필요가 있다. 격조사 사용은 두 낱말을 조합하는 시기부터 출현하고, 또래와 상 호작용하는 영유아 시기인 만 2-3세 경에 발달하는 것으로 알려져 있다. 그런데, 아동의 격조사 발달 순서에서 주격조사가 목적격조 사보다 더 빨리 출현하는 것으로 보고되고 있다(Lee, Lee, \& Lee, 1997; Lee \& Kwon, 1999; Pae, 1997). 따라서, 격조사가 의문사와 결 합하였을 때 또한 '누구+가'의 형태가 '누구+를'보다 먼저 발달하 는 것은 격조사 발달 순서와 일치하는 것으로 보인다.

'누가'가 ‘누구를'보다 발달이 빠른 이유는 한국어 문장 어순의 규범성으로도 설명이 가능하다. 한국어는 동사 후치어로 주어+목 적어+동사의 문장 어순이 규범 어순으로, 동사가 후치되는 어순이 유지되는 한, 비교적 자유로운 문장 어순을 가지고 있는 언어이다 (Sohn, 2006). 그럼에도 불구하고, 문장 어순의 규범성이 노화에 영 향을 미친다는 연구는 다양하게 보고되었다(Sung, 2015a, 2015b, 2017; Sung, Yoo, Lee, \& Eom, 2017). 이러한 어순 전형성을 의문사 격조사와 연결하여 살펴보면, '누가+누구를+동사'로 이루어진 문 장에서 '누가'를 물어볼 경우, 문장의 주어에 위치한 명사구를 활성 화하게 되어 '누구를'이라는 목적격 명사구를 물어보는 질문에 비 해 규범성에 기반한 의문사 처리가 더 용이해질 수 있음을 예측할 수 있다. 반면 목적격 위치에 있는 '누구를'로 시작하는 의문문의 경우는, 목적어가 앞에 위치하는 비규범 어순으로 '누가'를 문두에 서 물어보는 의문문에 비해 처리과정에서 부담이 증가할 수 있다. 하지만, 이러한 가설을 한국어 의문사와 격조사 결합 유형에 따라 노화와 연결하여 살펴본 연구는 전무한 실정이다.

영어권 Dickey \& Thompson (2009) 연구에서 브로카 실어증 환 자를 대상으로 '누구를(wh-) 의문사 질문에 대한 언어처리 능력을 연구하였다. 연구자는 대상자들에게 그림과 이야기를 동시에 들려 준 후, 다시 동일한 그림을 보여주며 의문사 질문을 제시하고 그에 맞는 그림을 선택하게 하였다. 질문은 목적어를 찾는 능동 질문과, 피동 질문 두 가지로 진행되었다. 그 결과, 능동 목적격 질문에서 정 상군의 정반응률이 $100 \%$ 인데 반해, 실어증 대상군의 정반응률은 $36 \%$ 로 매우 저조한 수행률을 보였다. 또한, 목적격 피동 질문에서
정상군의 정반응률이 $90 \%$, 실어증 대상군의 정반응률은 단지 $20 \%$ 에 그쳤다. Neuhaus와 Penke (2008) 연구에서는, 독일 실어증 환자들의 의문문 이해능력을 평가하였다. 그 결과, 독일 실어증 대 상자들 역시 정상군에 비해 낮은 정반응률을 보였는데, 주어를 찾 는 의문사 질문에 비해 목적어를 찾는 의문사 질문에서 더 낮은 정 반응률을 보이는 것으로 나타났다. 한국의 경우, Park \& Choi (2011)의 한국 브로카 실어증의 의문문 이해에 관한 연구가 있다. 해당 연구에서는 의문문 종류에 따른 이해능력 차이와 의문문 이 해에서 어떠한 단서에 의존하는지를 살펴보았다. 연구 과제로 그림 을 보여주며 의문사 질문을 한 후, 대상자가 직접 대답하거나 그림 에서 고르도록 지시하였다. 연구 결과, 한국 브로카 실어증 환자들 은 주격 질문(누가)에 비해 목적격 질문(누구를)에서 저조한 수행 력을 보였다. 또한, 브로카 실어증 환자들은 문법적 단서 및 의미적 단서를 활용하는데 제한적이었지만 비교적 조사(case marker) 단 서를 활용하는 것으로 나타났다. 즉, 동일한 의문사사용 문장일 경 우, 조사에 의존하여 해당 의미역을 찾는 것을 알 수 있다. 이처럼 한국 브로카 환자들 역시 주격 처리보다 목적격 처리에서 더 어려 움을 보였고, 특히 의문사 이해에서 조사(case marker)는 의미역 찾 기에 중요한 역할을 하는 것을 알 수 있다.

비록, 한국인 노년층 대상으로 하는 의문사처리 연구는 거의 없 는 실정이지만, 한국의 의문사 사용빈도 연구를 통해 ‘누구’ 의문사 의 중요성에 대한 근거를 찾을 수 있다. Chang (1988)에 따르면, 14 만여 개의 어절로 구성된 코퍼스 중에 의문 체언- '누구류'에서 '누 구' 115 개, '누가' 54 개, '누굴' 3 개로 보고된다. 즉, '누가'의 사용빈도 가 ‘누굴(누구를)'에 비해 훨씬 많은 것을 알 수 있다. 이를 기반으 로, 한국 정상 노년층을 대상으로 하여 '누구(who' 의문사의 격조 사 유형에 따른 문장처리양상을 비교하는 연구가 필요한 실정이다.

문장 처리를 살펴보는 방법은 크게 문장 처리가 끝나는 지점(offline)에서 문장의 내용 및 문법적 오류에 대한 감별을 요구하는 과 제로 평가하는 방법과, 문장이 제시되는 실시간 처리(real-time processing 또는 online processing)를 살펴보는 방법으로 나누어진다. 실시간 처리과정을 잘 살펴볼 수 있는 패러다임으로 대표적인 것이 시선추적(eye-tracking) 방식이다. 시선추적기(eye-tracker)는 대상 자의 눈동자 움직임을 읽어주는 기계로, 시선이 머무는 지점 및 움 직임과 그 시간을 기록하기 때문에 과제수행에서 대상자의 시선이 얼마만큼 자극에 머무는지를 추출할 수 있다. 따라서 안구 움직임 은 그 사람의 지각 및 인지 활동의 중요한 지표가 되고 이를 통해 인 간의 정보습득 과정을 측정할 수 있다(Rayner, 1998; Hyönä, Lorch Jr, \& Kaakinen, 2002; Trueswell \& Gleitman, 2007). 본 연구에서는 $\mathrm{RED}$ 방식을 이용하였는데, RED 방식은 컴퓨터, 텔레비전 등의 모 
니터에 시선추적장비를 부착시켜 대상자의 안구 위치와 반사광 위 치를 파악하여 시선의 움직임을 측정하는 방식을 의미한다. 이 방 식은 대상자의 신체에 장비를 부착하지 않는 비침습적 방법이라는 장점이 있다. 시선추적연구에서는 주로 시선고정시간(fixation duration), 시선고정시간 비율(fixation proportion), 시선고정횟수(fixation count) 등의 측정치를 사용한다. 시선고정시간이란, 자극에 시선이 머무는 시간을 의미하며 밀리세컨드 $(\mathrm{ms})$ 로 기록된다. 시선 고정시간 비율이란, 시선이 고정된 시간을 전체시간에 대한 비율로 나타낸 것을 의미한다. 시선고정시간은 보통 평균적으로 180-330 (ms) 범위에 머무는데, 사람에 따라 다양한 범위로 나타난다(Henderson \& Pierce, 2008). 그런데 다양한 문헌에서 시선고정이 오래 일어날수록 그 처리 과정이 복잡한 것으로 보고되었다(Ashby, Rayner, \& Clifton, 2005; Hutzler \& Wimmer, 2004). 또한, 시선고정시 간은 과제 유형에 따라 상이하게 나타날 수 있는데, 읽기에서보다 장면 인식에서 더 길다(Rayner, 2009). 즉, 시선고정시간의 범위는 다른 과제보다 시각적 처리에서 가장 크게 나타나는데 이것은 장 면 인식에서 시선고정이 읽기에 비해 더 넓은 범위에서 오는 정보를 처리하기 때문이다.

이처럼 시선추적기는 과제 수행력 결과만으로는 알 수 없는 정보 처리 상황을 유추하는 데 매우 효과적이고 유용한 방법이다. 현재 까지 많은 시선추적을 활용한 연구는 주로 아동을 대상으로 하는 읽기 연구에서 많이 진행되어 왔으나 점차적으로 성인을 대상으로 하는 시선추적 연구가 늘어나는 추세이다. 또한, 읽기 과제 위주의 연구였던 과거와 달리 최근에는 청각적 과제를 포함한 문장처리과 제를 사용한 연구가 진행되고 있다. Dickey 외 $(2007,2009)$ 연구에 서는 실어증 환자들을 대상으로 그림과 청각적 언어자극을 제시하 고 의문사 질문을 통해 그에 따른 목표 그림을 고르는 시선추적 연 구를 진행하였다. 그 결과, 문장이 제시되는 구간에서는 실어증 환 자와 정상성인의 큰 차이가 없었으나, 문장이 제시되는 이후 구간 (post-offset region)에서 실어증 환자의 시선고정비율이 증가하였 다. 이는 실어증 환자의 문장처리 효율성이 정상성인에 비해 떨어지 기 때문에 답을 결정(Decision making)하는 과정이 늦게 나타나는 것을 의미하고, 목표자극과 방해자극(distractor)을 구분하는 문장 처리에서 정상성인과 차이가 나는 것으로 해석할 수 있다. 한국에 서도 시선추적을 활용한 노년층의 연구(Jo, 2019; Choi, 2019; Hwang, 2019)가 다양하게 진행되어 왔다. Jo (2019) 연구에서는, 노년층을 대상으로 단어제인 과제를 실시하였다. 그 결과, 노년층의 정반응 률 및 반응속도가 청년층에 비해 유의하게 낮았다. 또한, 구간별 시 선고정비율에서 노년층의 시선고정비율이 청년층에 비해 유의하 게 낮았다. Hwang (2019) 연구에서는 의미역 과제를 이용하여 노
년층과 청년층의 반응시간과 시선고정비율을 비교하였다. 그 결과, 의미역 예측 정도가 낮은 조건에서 노년층의 반응시간이 청년층에 비해 유의하게 감소되었다. 또한, 시선고정에 있어서 노년층의 시선 고정비율이 청년층에 비해 낮은 것으로 나타났다. 이처럼 노년층의 언어처리에 대한 많은 시선추적 연구가 진행되었고, 시선추적 데이 터를 통해 실시간 처리과정 비교가 가능하였다.

그러나 아직 의문사를 활용한 시선추적 문장처리 연구는 없는 실정이다. 따라서 본 연구에서는 의문사를 이용하여 노년층에게서 나타나는 문장처리 연구를 진행하고자 한다. 본 연구자는 의문사 중 일찍 발달하는 것으로 알려진 '누구’ 의문사를 본 연구과제에서 사용할 의문사로 선정하였고, 이를 Sung (2015a) 연구에서 정의한 규범성에 따라 의문사와 규범성을 연결지었다. 한국어에서 의문사 는 의문사의 이동 여부에 영향을 받지 않는 특징을 가지기 때문에 (Yoon \& Kim, 2008), 의문사의 위치에 따른 문법적 오류는 발생하 지 않는다. 이러한 이유에 근거하여 본 연구에서는 '누가' 및 '누구 를' 의문사를 모두 문장의 맨 앞에 위치시켜 의문문을 구성한다. 즉, 본 연구자는 규범성 '누가' 의문사 질문에서의 수행력과 비규범성 '누구를' 의문사 질문에서의 수행력을 비교하고, 나아가 시선추적 데이터를 이용하여 시선고정시간(Fixation duration) 및 시선고정비 율(Fixation proportion)과 같은 질적 양상을 비교하고자 하였다.

구체적인 연구 질문은 다음과 같다.

1) 누구(who) 의문사의 격조사 유형(-가/-를)에 따라 두 집단(청 년층 vs. 노년층) 간 문장처리과제에서의 정반응률 차이가 유 의한가?

2) 누구(who) 의문사의 격조사 유형(-가/-를)에 따라 두 집단(청 년층 vs. 노년층) 간 문장처리과제에서의 시선고정시간(fixation duration) 차이가 유의한가?

3) 누구(who) 의문사의 격조사 유형별 구간에 따른 두 집단(청년 층 vs. 노년층) 간 문장처리과제에서의 시선고정시간비율(fixation proportion) 차이가 유의한가?

\section{연구방법}

\section{연구대상}

본 연구의 대상은 청년 21 명(남자 3 명, 여자 18 명)과 노년 17명(남 자 3 명, 여자 14 명), 총 38 명이다. 두 집단은 (1) 한국어를 모국어로 사용하고, (2) 건강선별기준(Christensen, Multhaup, Nordstrom, \& Voss, 1991)에 근거한 기준에 따른 신경학적 및 정신적 병력이 보 고되지 않으며, (3) 교육연수가 9년 이상이고, (4) 서울 및 인천, 경기 도 지역에 거주하며, (5) 한국판 간이정신상태 검사(Korean-Mini 
Mental State Examination; K-MMSE, Kang, 2006) 점수가 연령 및 교육연수에 비해 $16 \%$ ile 이상으로 정상 범위에 해당하고, (6) 자가보 고(self-report)를 통한 시력 설문에서 이상이 없고, (7) 순음 청력검 사에서 역치 $50 \mathrm{dBHL}$ 이하인 기준을 만족하였다. 청력검사 역치 기준은, 본 연구에서 사용하는 음성자극을 기준으로 하였다. 노년 층에게는 추가로 언어기억검사(Seoul Verbal Learning Test; SVLT, Kang \& Na, 2003)를 실시하며, 점수가 연령 및 교육연수에 비해 $16 \%$ ile 이상의 정상범주에 해당하는 자를 선별하였다. 본 연구는 본교 연구윤리위원회(IRB)의 심의를 거쳐 위원회 승인하에 진행되 었다(과제 승인번호 201909-0008-01). 청년층과 노년층 집단의 교육 연수에서 통계적으로 유의한차이가 나타나지 않았다 $\left(F_{(1,37)}=2.131\right.$, $p=0.163)$. 또한, 청년층과 노년층의 성별 비교를 위해 카이제곱 검 정을 실시한 결과, 집단과 성별 간 분포 차이가 유의하지 않았다 ( $p=.778)$.

연구에 참여한 대상자의 정보는 다음의 Table 1에 제시된 바와 같다.

\section{연구 과제}

\section{이야기 및 그림 자극}

본 실험에는 선행연구인 Dickey 등(2009)의 패러다임을 한국어 에 맞게 적용하여 과제를 개발하였다. 하나의 이야기는 3 문장으로 구성된다. 첫 문장은 부사(어느 날), 주어 1 , 주어 2 , 장소, 서술동사 (-있다)가 포함된 문장이다. 두 번째 문장은 주어, 목적어, 타동사로 구성되며, 행위자가 대상자에게 하는 행위가 설명된다. 마지막 문 장은 방해문장으로, 부사(지금), 제 3 의 주어와 자동사, 지시어(고르

Table 1. Demographic information on participants

\begin{tabular}{|c|c|c|c|c|c|c|}
\hline \multirow{2}{*}{ Group } & \multicolumn{2}{|c|}{ Gender } & \multicolumn{2}{|c|}{ Age (year) } & \multicolumn{2}{|c|}{ Education (year) } \\
\hline & Male & Female & Mean (SD) & Range & Mean (SD) & Range \\
\hline Young ( $N=21)$ & 3 & 18 & $23.33(4.75)$ & $19-34$ & $14.24(2.19)$ & $12-18$ \\
\hline Old (N=17) & 3 & 14 & 64.41 (2.96) & $60-70$ & $13.06(2.80)$ & $9-18$ \\
\hline Total & 6 & 32 & 41.71 (21.08) & $19-70$ & $13.71(2.51)$ & $9-18$ \\
\hline
\end{tabular}

Table 2. Example of the story and question stimuli

\begin{tabular}{ll}
\hline \multicolumn{1}{c}{ Story stimuli } \\
\hline Sentence & One day, a squirrel and an earthworm were on the playground. \\
1 & The squirrel shook the earthworm. \\
3 & The crow warbled. \\
$\begin{array}{ll}\text { Type of question } \\
\text { who+nom }\end{array}$ & Now, choose who shook the earthworms. \\
who+acc & Now, choose who the squirrel shook. \\
\hline
\end{tabular}

세요)로 구성된다. 한 이야기 자극에 사용되는 모든 명사는 음절 수 가 동일하며 첫 음소가 중복되지 않는 조건을 만족한다(예: 다람쥐 (agent), 지렁이(theme), 놀이터(place), 까마귀(distractor)). 이야기 자극의 예시는 Table 2에 제시된 바와 같다. 음절 수와 음소에 대한 조건을 모두 만족시키는 서로 다른 이야기 24 가지를 만드는 과정에 서, 그림- 어휘 연결 타당도 검증을 진행하였다. 이를 위해, 정상성 인 12 명에게 본 실험에 사용되는 어휘자극과 그림쌍을 제시하고 0 점(매우 관련 없음)부터 4점(매우 관련 있음)까지 그림과 의미 관 련성에 대해 5점 척도의 평가를 실시하였다. 그 중 3점 미만을 받은 8 개의 항목은 새로운 그림으로 교체하여 2 차 그림-어휘 연결 타당 도를 진행하였고, 최종적으로 목표 자극 및 방해 자극 총 144 개를 선정하였다. 본 실험의 이야기 자극은 총 36 개(본 실험자극 24 개 + filler 12 개)이고, 각 이야기당 4 개의 그림을 사용하여 총 144 개의 그 림을 사용하였다. 선행연구 (Dickey et al., 2009)와 동일하게, 그림 4 장이 한 스크린 화면에 구성되며 각 그림은 컴퓨터 화면의 모서리 에 한 개씩 배치된다. 그림자극의 예시는 Figure 1에 제시된 바와 같 다. 다음으로, 이야기에 사용되는 모든 자동사와 타동사는 동아 새 국어사전 제5판(Lee, 2004), 현대 국어 자동사 연구(Han, 2000) 및 국립국어원 표준대국어사전을 통해 확인작업을 거친 후에 선정하 였고, 그 중 결과에 영향을 미칠 수 있는 타동사는 빈도수 100 이상 의 고빈도 어휘(Seo, 1988)로 최종 선정하였다. 실험에 사용된 모든 이야기 및 질문 목록은 Appendix 1에 첨부하였다. 질문은 총 2가지 유형으로 나뉘는데, 통사적 구조의 통제를 위해 첫 음절에 부사 '지 금'을 동일하게 배치하였다. 이것은 시선고정 결과추출 시 첫 구간 에서 안정되지 않은 안구 움직임에 따른 데이터 손실을 방지하기 위함이다. 의문사(누가/누구를)는 문장에서 두 번째 어절에 동일하 게 배치하여 질문 유형에 따른 통사구조의 차이가 없도록 하였다.

모든 그림자극은 화면에 시작적으로 제시, 이야기자극 및 질문 자극은 스피커를 통해 청각적으로 제시된다. 이야기자극은 그림자

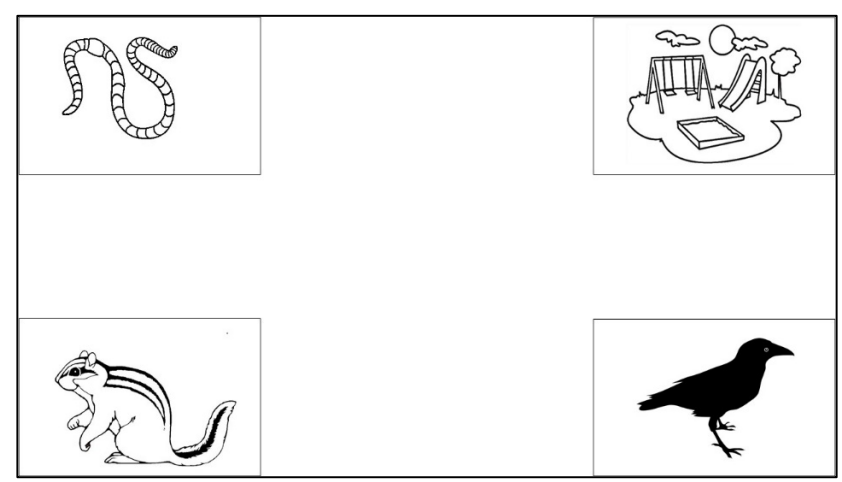

Figure 1. Example of picture stimuli. 
극과 동시에 제시되는데, 제시시간은 평균 10 초이고, 질문자극 제 시시간은 평균 4.1 초이다. 실험자극 제시 순서는 연구절차에 더 자 세하게 기술하였다.

\section{자극 배열}

이야기자극은 총 36 개로, '누구를' 유형에 대한 12 가지, '누가' 유 형에 대한 12 가지 그리고 filler 문항 12 가지로 구성된다. 피험자가 실험을 미리 예상하여 연구결과가 왜곡되는 것을 방지하기 위해 매 꿈질자극(Filler stimuli)을 배치하였는데, 필러는 목표 이야기 자극 과 유사하게 구성하여 '어디(place)', '왜(why)', '언제(when)'를 묻는 형식으로 진행하였다. '누구+가' 유형, '누구+를' 유형, Filler의 비율 은 1:1:1로 유사무선배치(pseudo-randomization)하였다. 또한, 대 상자가 미리 문제 유형을 예측하는 것을 방지하기 위하여, 같은 유 형이 연달아 2 번 이상 나오지 않도록 구성하였다. 더불어, 목표자 극(답)의 위치도 같은 위치에 2 번 이상 연속하여 나오지 않도록 하 였다.

\section{연구 도구}

\section{음성 자극 및 녹음기기}

음성 자극은 성인 여성의 목소리로 녹음되었다. 녹음은 방음시 설이 갖춰진 조용한 실험실에서 진행하였고, 녹음기는 Sony사의 ICD-TX650을 사용하였으며 마이크와 입의 거리는 $20 \mathrm{~cm}$ 로 하여 녹음하였다. 문장의 읽기 속도는 Kwon, Kim, Choi, Na 그리고 Lee (1998)에 따른 3.45 (초)음절과 Shin과 Han (2003)에 따른 4.4 (초) 음절의 중간값인 3.9 (초)로 조절하였다. 녹음된 음원은 Praat 프로 그램을 이용하여 편집하였다.

모든 이야기 및 질문은 청각적으로 제시하였다.

\section{시선추적기(Eye-tracker)}

본 연구에서는 시선추적기를 이용하여 안구움직임 자료를 수집 하였다. 안구추적기계는 SensoMotoric Instruments사의 모니터에 remote eye-tracking systems (RED)을 고정시켜 사용하였다. 시선 추적기와 더불어, 시선추적기와 대상자의 눈 사이를 일정하게 유지 하기 위해, 대상자의 얼굴을 고정시킬 수 있도록 턱 고정대(chin-rest) 를 자체적으로 제작하여 사용하였다. 실험 설계는 SMI (Senso Motoric Instruments)사의 Experiment 3.7 프로그램을 이용하였고 분 석을 위해서는 Begaze 3.7 프로그램을 사용하였다.

\section{연구 절차}

먼저, 대상자 개별 선별검사를 실시하였다. 선별검사에서는 인지
및 언어검사와 청력검사를 실시하였다. 그 후 본 실험을 진행하였 고 실험은 소음이 통제된 쉴드룸 안에서 피험자 개별적으로 참여 하는 방식으로 진행하였다. 피험자는 시선추적기가 설치된 컴퓨터 앞에 앉는데, 이때 안구의 움직임을 고정하기 위해 턱받침대에 얼 굴을 고정하였다. 피험자가 턱을 받침대에 고정하면, 연구자는 그 들에게 얼굴이 고정된 상태에서 안구만 움직이도록 지시하였다. 자 세 고정이 끝나면, I view X 프로그램을 구동하여 안구운동이 잘 추적되고 있는지 사전 보정작업을 거쳤다. 보정단계 (calibration) 는 대상자의 시선이 시선추적기가 허용하는 각도 범위 내에 있는지 맞추는 과정이다. 보정작업에서 동공의 최대편차가 $\mathrm{X}, \mathrm{Y}$ 축 모두 0.5 이하의 범위(Holmqvist et al., 2011) 내에 있음을 확인한 후 다음 단 계로 넘어갔고 보정작업이 끝나면 바로 연습 문항을 실시하였다. 연 구자는 대상자에게 '먼저 그림과 함께 이야기가 제공됩니다. 그 후, 삐 소리와 함께 그림이 잠시 사라집니다. 곧 동일한 그림이 제시되 면서 이번에는 질문이 제시되는데, 질문을 주의 깊게 들으신 후 그 에 맞는 답이라고 생각되는 그림을 키보드로 눌러주세요.'라는 지 시사항을 들려주었다. 연습문제에서는 주어(subject) 찾기, 목적어 (object) 찾기, 방해 자극(distractor) 찾기, 장소(place) 찾기 등을 묻 는 질문 총 4 회를 연습하였다. 대상자가 연습 문항에서 실험에 대해 완전히 이해가 완료되면, 본 문항을 실시하였다. 이때부터 연구자 는 쉴드룸 밖에서 피험자의 수행을 관찰하였다.

실험의 단계는 다음과 같다. 1) 화면에 4 개의 그림이 동시에 제시 되면서, 청각적 이야기 자극이 함께 제시된다. 따라서 대상자는 그 림을 보면서 이야기를 듣고, 질문에 대비하여 이야기를 기억하고 있 어야 한다. 2)그 후, 삐- 소리와 함께 컴퓨터 화면에 있던 그림이 잠 시 사라진다. 3) 동일한 그림들이 화면에 다시 제시됨과 동시에 질 문자극이 청각적으로 제시된다. 이 단계에서 대상자는 질문을 듣 고 그에 맞는 답을 키보드로 선택한다. 시선추적은 마지막 단계인 3 단계에서만 실시된다. 즉, 질문을 듣고 답을 고르는 실시간 처리과 정이 기록된다. 실험이 절반 진행되면 다시 한번 보정작업을 거치게 된다. 이때, 연구자는 피험자의 상태를 살피며 쉬는 시간을 가질지 확인한다. 피험자가 쉬는 시간을 원하는 경우 충분히 쉬는 시간을 가졌으며, 그렇지 않은 피험자의 경우 중간 보정단계를 진행한 후 바로 나머지 실험을 진행하였다.

실험 순서도는 Figure 2와같다.

\section{자료 분석}

본 연구의 종속변수는 정반응률, 시선고정시간, 시선고정비율이 다. 정반응률(Accuracy)은 Begaze3.7 프로그램을 이용하여 proto$\mathrm{col}$ 파일을 추출하였고 이 자료를 다시 Microsoft사의 Excel 2016에 


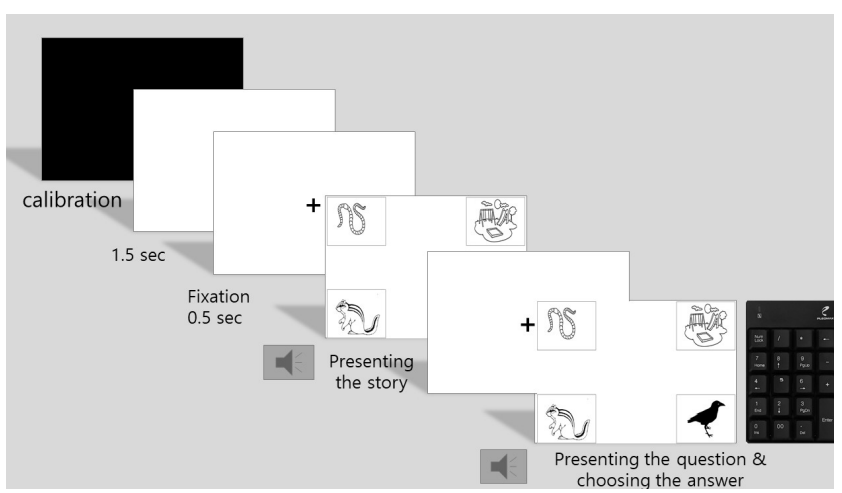

Figure 2. A display of experimental stimulus.

서 계산하였다. 또한, 시선추적 데이터는 $100 \mathrm{~ms}$ 이상을 시선고정 단위로 지정하여 자료를 추출하였고 시선추적 기록에 있어서 반응 시간은 밀리세컨드 $(\mathrm{ms})$ 단위로 측정하였다. 추출은 오른쪽 눈, 비 율(proportion)을 기준으로 추출하였다. 또한, $\pm 3 \mathrm{SD}$ 를 벗어나는 값은 이상값(outlier)으로 처리하여 분석에서 제외하였다(Spit \& Rispens, 2019; Lee, Kim, \& Park, 2019).

\section{정반응률(Accuracy)}

본 연구에서는 대상자가 화면에 제시된 4 개의 그림자극 중에서 올바른 목표자극을 고른 경우 1점, 그렇지 않은 경우 0점으로 채점 하여 정반응률을 계산하였다. 정반응한 문항 수를 전체 문항 수로 나눈 후 100 을 곱하여 퍼센트를 산출하였다. 예를 들어, '누구+가' 유형에서 9 문제를 정반응 하였다면, $(9 / 12) \times 100=75 \%$ 가 된다. 각 유형별 총 문항 수는 12 개이다.

\section{목표자극의 시선고정시간(Fixation duration)}

본 연구에서는 문장처리과제에서 목표자극에 대한 시선고정시 간(fixation duration)을 수집하고 heap map 분석을 하였다. 시선고 정시간은 대상자가 질문자극을 들을 때 시선이 목표자극에 고정되 는 총 시간을 의미하며, 제시된 시선고정시간은 $100 \mathrm{~ms}$ 이상 Area of Interest (AOI)에 머물렀을 때 기록된 값이다. Heat map은 시선 추적기계(eye-tracker)를 사용하여 측정된 데이터를 기반으로 Begaze 프로그램을 이용하는 분석방법 중 하나로, 기록된 시선고정 데이터의 정도에 따라 화면에 여러 색상으로 표현하여 시선양상을 시각화 하는 방법이다. 즉, heap map을 통해 대상자가 어느 곳을 가 장 많이 보았는지를 알 수 있다.

\section{과제별 구간에 따른 시선고정비율(Fixation proportion)}

본 연구에서는 대상자에게 주어지는 질문자극을 시간 흐름에
따라 4가지 구간(NP1, NP2, VP1, VP2)으로 나누어 각 구간의 시 선고정비율을 계산하였고, 유형별 구간예시는 Appendix 2에 제시 하였다. 시선고정비율은 질문자극이 청각적으로 제시되는 과정에 서 측정된 대상자의 시선고정에 대한 비율을 의미하고, 이때 하나 의 문장으로 이루어진 질문자극을 4 개의 구간으로 나눠서 비교한 다. 따라서, 구간의 의미는 목표자극을 본 시간의 구간을 의미한다. 시선고정비율은 대상자의 시선이 각 구간에서 목표자극에 머문 시 간을 그 구간이 제시되는 총 시간으로 나누어 비율을 계산하였다. 예를 들어, NP1 구간이 $3,000 \mathrm{~ms}$ 제시되는 동안 대상자가 목표자 극을 본 시간이 총 $300 \mathrm{~ms}$ 인 경우, 이때 NP1 구간의 시선고정비율 은 0.1 이 된다.

\section{자료 통계적 처리}

격조사 유형(-가/-를)에 따른 누구(who) 의문사 질문에서 정반 응율 및 시선고정비율의 집단 간 차이가 유의한지 알아보기 위하 여 집단(청년층 vs. 노년층) $\times$ 질문유형(누가 vs. 누구를)의 이원분 산분석(two-way mixed ANOVA)을 실시하였다. 또한, 질문유형 별 구간에 따른 집단 간 차이가 유의한지 알아보기 위하여 구간(NP1 vs. NP2 vs. VP1 vs. VP2) × 집단(청년층 vs. 노년층)의 이원분산분 석(two-way mixed ANOVA)을 실시하였다. 집단통계 분석은 SPSS ver. 20 (SPSS Inc., Chicago, IL, USA) 프로그램을 사용하였다. 본 연구에서는 유의수준 .05 에서 검증하였으며, 구형성(sphericity) 검 정이 만족되지 않을 경우에, Greenhouse-Geisser 분석을 적용한 $p$ value 값에 근거하여 유의성을 보고하였다.

\section{연구결과}

\section{누구(who) 의문사의 격조사 유형(-가/-를)에 따른 집단 간 정반응률 차이}

문장처리과제에서 누구(who) 의문사의 격조사 유형(-가/-를)에 따른 집단 간 정반응률의 차이를 알아보았다. 정반응률의 집단 간 차이를 통계적으로 분석하기 위해 집단 $\times$ 유형 이원혼합분산분석 (two-way mixed ANOVA)을 실시한 결과, 청년층은 평균 97.62\%, 노년층은 $88.73 \%$ 의 정반응률을 보였고 통계 결과 및 그래프는 Table 3, Figure 3과 같다.

먼저 청년층과 노년층 간 집단에 대한 주효과가 통계적으로 유의 하였다 $\left(F_{(1,36)}=21.450, p<.001\right)$. 즉, 노년층 집단의 평균 $84.07 \%$ 이 청년층 집단에서의 평균 $97.22 \%$ 에 비해 유의하게 낮은 것으로 나 타났다. 다음으로, 유형에 대한 주효과가 또한 통계적으로 유의하 였다 $\left(F_{(1,36)}=6.414, p<.05\right)$. 즉 '누구+를' 유형에서 정반응률이 '누 
Ji-Hye Jang, et al. • Aging effects on Processing Who-Questions: An Eye-Tracking Study

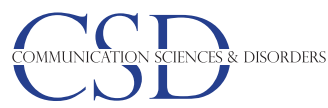

Table 3. Descriptive statistics of accuracy (\%) of task trials on the sentence processing for each group

\begin{tabular}{lcrllr}
\hline \multirow{2}{*}{ Group } & \multicolumn{2}{c}{ Who + nominative } & & \multicolumn{2}{c}{ Who + accusative } \\
\cline { 2 - 3 } \cline { 6 - 6 } & Mean (SD) & Range (\%) & & Mean (SD) & Range (\%) \\
\hline Young (N=21) & $97.62(4.67)$ & $83.33-100$ & & $96.83(4.91)$ & $83.33-100$ \\
Old (N=17) & $88.73(13.16)$ & $50-100$ & & $79.41(16.70)$ & $50-100$ \\
Total & $93.64(10.33)$ & $50-100$ & & $89.03(14.51)$ & $50-100$
\end{tabular}

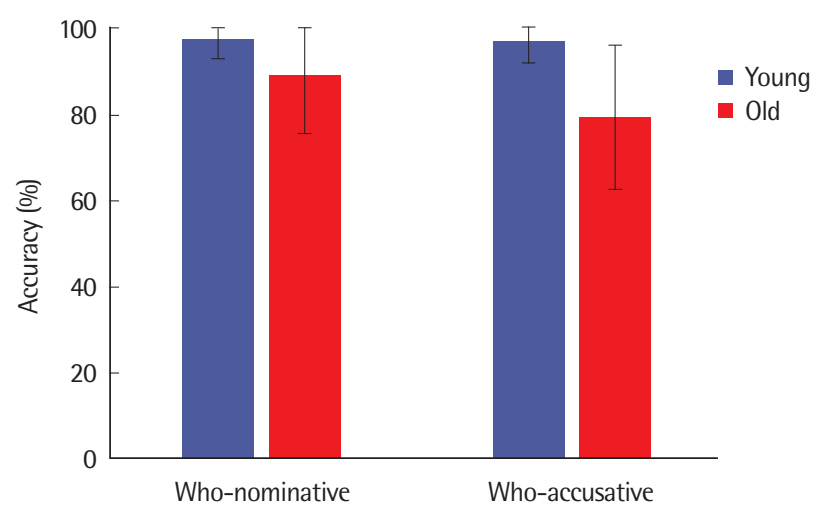

Figure 3. Accuracy of task trials for each type in Young and Old groups.

구+가' 유형에서의 정반응률에 비해 유의하게 낮은 것으로 나타났 다. 마지막으로, 집단과 유형에 대한 이차 상호작용이 통계적으로 유의하였다 $\left(F_{(1,36)}=4.557, p<.05\right)$. 즉, '누구+를' 유형에서 집단 간 차이가 '누구+가' 유형에서 집단 간 차이에 비해 유의하게 큰 것으 로 나타났다.

\section{문장처리에서 누구(who) 의문사의 격조사 유형(-가/-를)에 따른 집단 간 목표자극의 시선고정시간(fixation duration) 차이}

문장처리과제에서 의문사의 격조사 유형에 따른 집단 간 목표자 극의 시선고정시간의 차이를 알아보았다. 통계적 차이를 분석하기 위해 이원혼합분산분석(two-way mixed ANOVA)을 실시하였다. 기술통계 결과 및 그래프는 다음의 Table 4, Figure 4 와 같다.

집단에 대한 주효과가 통계적으로 유의하지 않았다 $\left(F_{(1,31)}=1.241\right.$, $p=.274)$. 즉, 노년층 집단의 평균 $922.75 \mathrm{~ms}$ 와 청년층 집단의 평균 $845.771 \mathrm{~ms}$ 에서 유의한 차이가 나타나지 않았다. 다음으로, 유형에 따른 주효과가 통계적으로 유의하였다 $\left(F_{(1,31)}=8.847, p<.05\right)$. 즉, '누구+가' 유형의 평균 $962.56 \mathrm{~ms}$ 가 ‘누구+를' 유형의 평균 803.63 $\mathrm{ms}$ 에 비해 유의하게 높은 것으로 나타났다. 마지막으로, 집단과 유 형에 대한 상호작용이 통계적으로 유의하지 않았다 $\left(F_{(1,31)}=.331\right.$, $p=.569$ ). 즉, '누구+가' 유형에서의 그룹 간 차이와 '누구+를' 유형 에서의 그룹 간 차이가 통계적으로 유의하지 않았다. 비록, 상호작
Table 4. Descriptive statistics of fixation duration (ms) of task trials on the sentence processing for each group

\begin{tabular}{lrr}
\hline Group & Who + nominative & Who + accusative \\
\hline Young $(\mathrm{N}=17)$ & $910.25(291.75)$ & $781.29(827.37)$ \\
Old ( $\mathrm{N}=16)$ & $1018.14(200.64)$ & $827.37(267.90)$ \\
Total & $962.56(253.83)$ & $803.63(248.04)$ \\
\hline
\end{tabular}

Values are presented as mean (SD).

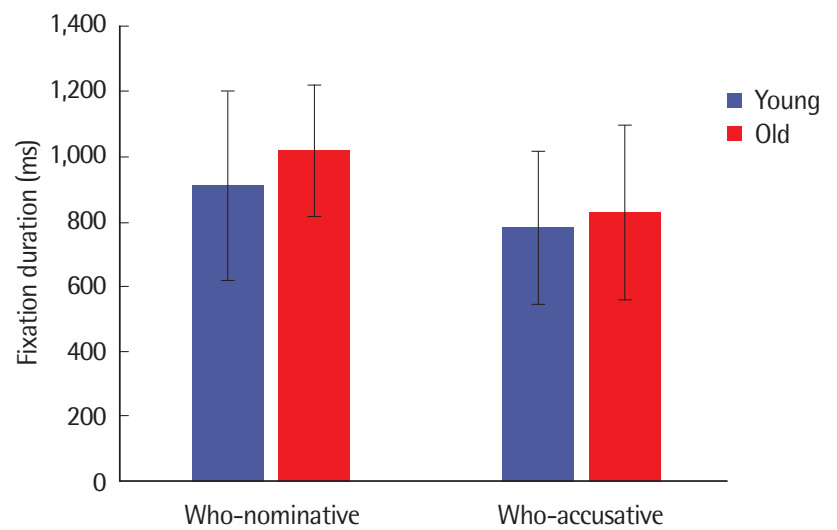

Figure 4. Fixation duration of task trials for each type in Young and Old groups.

용효과의 경우 통계적으로 유의하지 않았으나, heat map에서 집단 의 시선고정 양상 차이를 확인할 수 있었다. 문장처리과제에서 의 문사의 격조사 유형에 따른 집단 간 heat map은 다음의 Figure 5, Figure 6과 같다.

각 그림의 Area of Interest (AOI, 시선추적이 실행되는 지점)에 나타나는 집단의 시선고정시간을 시각화한 heat map을 살펴보면, 상호작용에 따라 시선의 분산 양상이 다름을 확인할 수 있다. Heat map에서 보이는 색깔로 시선고정시간의 정도 차이를 비교할 수 있 는데, 파란색은 약 $20 \mathrm{~ms}$ 이상, 초록색은 약 100-160 ms, 노란색은 약 $220 \mathrm{~ms}$ 이상, 빨간색은 약 $300 \mathrm{~ms}$ 이상 시선이 머문 것을 의미한 다. 전체적인 양상을 보면, 노년층은 청년층에 비해 목표자극( $\operatorname{tar}-$ get) 이외에도 다양하게 시선이 분산되었음을 알 수 있다. 또한, 유 형별로 살펴보면, '누구+가' 유형보다 '누구+를' 유형에서의 모든 집단의 시선 분산 정도가 강하게 나타났다.

\section{문장처리에서 누구(who) 의문사의 격조사 유형별 구간에 따른 집단 간 목표자극의 시선고정비율(fixation proportion) 차이}

누구 의문사의 격조사 유형별 구간에 따른 목표자극의 시선고정 비율 차이를 알아보았다. 구간은 총 4개로 나뉘며 NP1, NP2, VP1, $\mathrm{VP} 2$ 이다. '누구+가' 유형에서 NP1은 의문사-누가 부분, NP2는 목 


One day, a squirrel and an earthworm were on the playground.
The squirrel shook the earthworm. The crow warbled.
Now, choose who shook the earthworms. (target: squirrel)

Figure 5. Example of heat map of 'who+nominative' type.

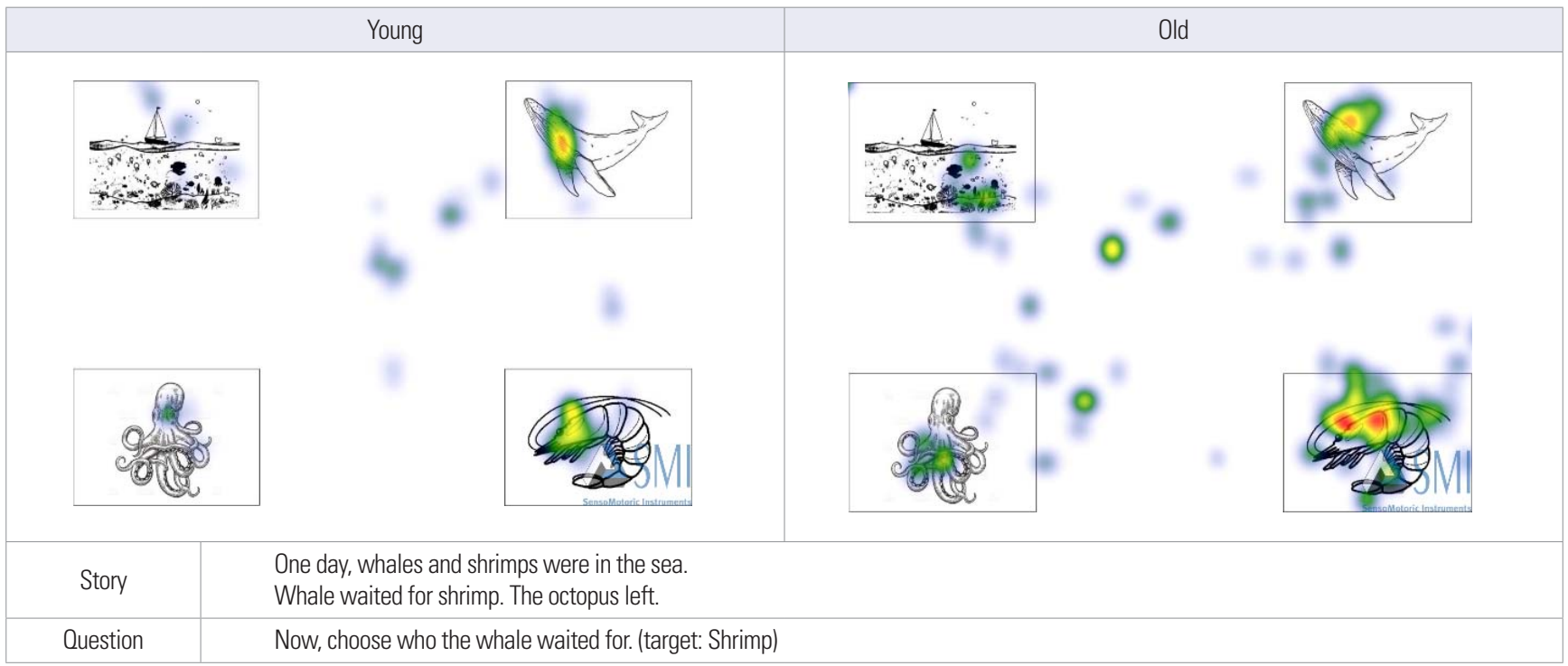

Figure 6. Example of heat map of 'who+accusative' type.

적어 부분, VP1은 동사 부분, VP2는 지시-고르세요이다. 반면, '누 구+를' 유형에서 NP1은 의문사-누구를 부분, NP2는 주어 부분, $\mathrm{VP} 1$ 은 동사부분, VP2는 지시-고르세요이다.

\section{‘누구(who)+가’ 유형 구간별 목표자극 시선고정비율 차이}

문장처리과제에서 의문사 '누구(who)+격조사 -가' 유형에서 구 간에 따른 집단 간 목표자극 시선고정비율(FP)의 차이를 비교하기 위해 청년층과 노년층을 집단 간 요인으로 지정, 4 개의 구간(NP1,
$\mathrm{NP} 2, \mathrm{VP} 1, \mathrm{VP} 2)$ 을 집단 내 요인으로 하는 이원혼합분산분석(twoway mixed ANOVA)을 실시하였다. 결과는 Table 5, Figure 7, Figure 8과 같다.

집단에 대한 주효과가 통계적으로 유의하지 않았다 $\left(F_{(1,31)}=.137\right.$, $p=.714)$. 다음으로, 구간에 대한 주효과 또한 통계적으로 유의하지 않았다 $\left(F_{(3,93)}=.103, p=.919\right)$. 마지막으로, 집단과 구간에 대한 이차 상호작용도 통계적으로 유의하지 않은 것으로 나타났다 $\left(F_{(3,93)}=.138\right.$, $p=.891)$. 
Ji-Hye Jang, et al. • Aging effects on Processing Who-Questions: An Eye-Tracking Study

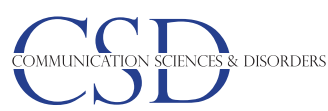

Table 5. Descriptive statistics of target stimulus fixation proportion for each group in 'who + nominative' type

\begin{tabular}{lcccc}
\hline Group & NP1 & NP2 & VP1 & VP2 \\
\hline Young $(N=17)$ & $0.28(0.16)$ & $0.30(0.15)$ & $0.28(0.11)$ & $0.29(0.16)$ \\
Old $(\mathrm{N}=16)$ & $0.29(0.16)$ & $0.30(0.15)$ & $0.31(0.15)$ & $0.29(0.17)$ \\
Total & $0.28(0.16)$ & $0.30(0.15)$ & $0.30(0.13)$ & $0.29(0.16)$ \\
\hline
\end{tabular}

Values are presented as mean (SD).

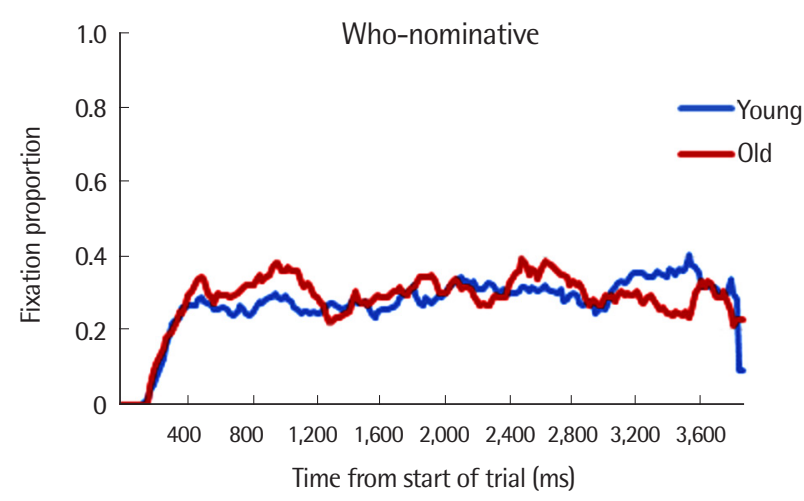

Figure 7. Fixation proportion of the target over time of 'who+nominative' type in both groups.

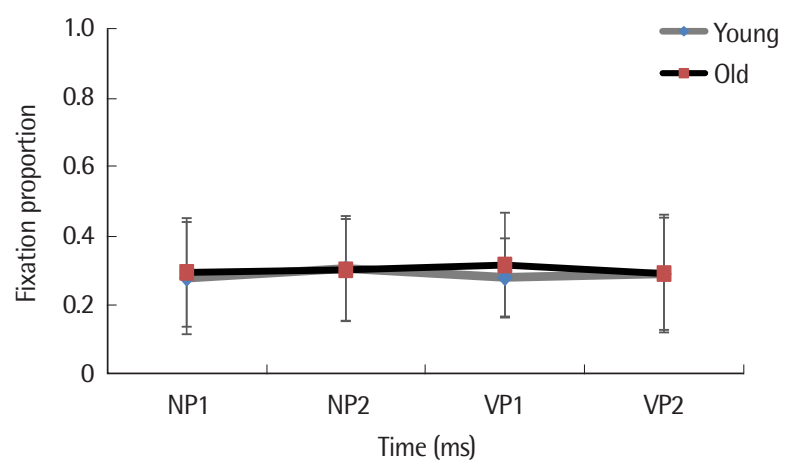

Figure 8. Fixation proportion of the target for each phrase in 'who+nominative' type of both groups.

\section{‘누구(who)+를' 유형 구간별 목표자극 시선고정비율 차이'}

문장처리과제에서 의문사 '누구(who)+격조사 -를' 유형에서 구 간에 따른 집단 간 목표자극 시선고정비율(FD)의 차이를 비교하기 위해 청년층과 노년층을 집단 간 요인으로 지정, 4 개의 구간(NP1, $\mathrm{NP} 2, \mathrm{VP} 1, \mathrm{VP} 2$ )을 집단 내 요인으로 하는 이원혼합분산분석(twoway mixed ANOVA)을 실시하였다. 기술통계 결과 및 그래프는 Table 6, Figure 9, Figure 10과 같다.

집단에 대한 주효과가 통계적으로 유의하지 않았다 $\left(F_{(1,31)}=.264\right.$, $p=.611)$. 다음으로, 구간에 대한 주효과가 통계적으로 유의하였다 $\left(F_{(3,93)}=16.463, p<.001\right)$. 이에 따라 Bonfferoni를 사용하여 사후검
Table 6. Descriptive statistics of target stimulus fixation proportion for each group in 'who + accusative' type

\begin{tabular}{lcccc}
\hline Group & NP1 & NP2 & VP1 & VP2 \\
\hline Young (N=17) & $0.15(0.10)$ & $0.24(0.15)$ & $0.36(0.16)$ & $0.41(0.14)$ \\
Old (N=16) & $0.22(0.14)$ & $0.25(0.12)$ & $0.31(0.18)$ & $0.31(0.13)$ \\
Total & $0.18(0.13)$ & $0.24(0.13)$ & $0.34(0.17)$ & $0.36(0.15)$ \\
\hline
\end{tabular}

Values are presented as mean (SD).

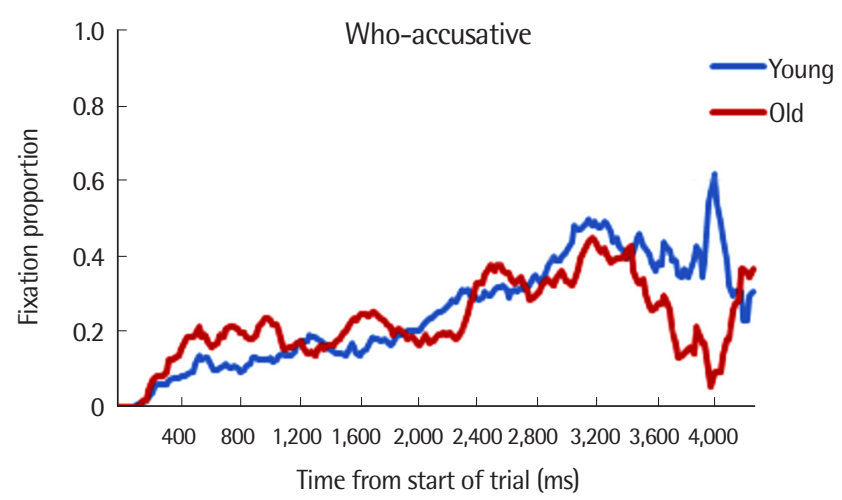

Figure 9. Fixation proportion of the target over time of 'who+accusative' type in both groups.

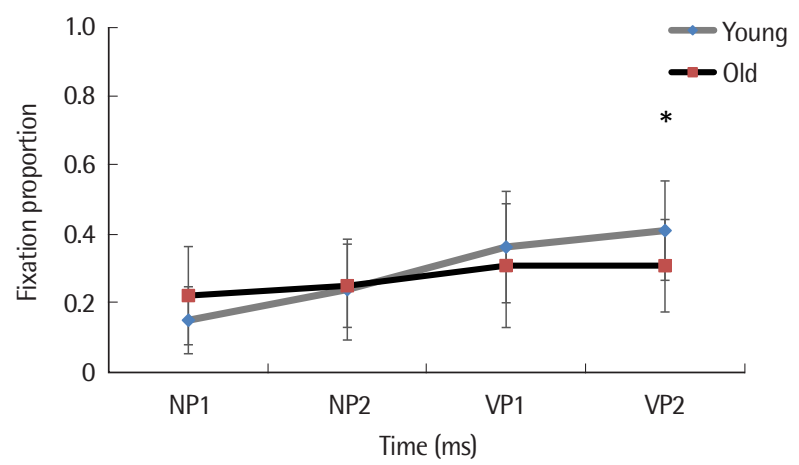

Figure 10. Fixation proportion of the target for each phrase in 'who+accusative' type of both groups.

${ }^{*} p<.05$.

정을 실시하였다. 그 결과, NP1과 $\mathrm{VP} 1$ 차이 $(p<.001), \mathrm{NP} 1$ 과 VP2 차이 $(p<.001), \mathrm{NP} 2$ 와 $\mathrm{VP} 1$ 간 차이 $(p<.05), \mathrm{NP} 2$ 와 $\mathrm{VP} 2$ 간 차이 $(p<.05)$ 는 통계적으로 유의하였으나, NP1과 NP2 차이 $(p=.099)$ 및 $\mathrm{VP} 1$ 과 $\mathrm{VP} 2$ 간차이 $(p=1.00)$ 는 유의하지 않았다.

마지막으로, 집단과 구간에 대한 이차상호작용이 통계적으로 유 의하였다 $\left(F_{(3,93)}=3.623, p<.05\right)$. 유의한 이차상호작용에 대한 사후 검정으로 각 구간별로 집단 간 차이가 있는지 알아보기 위해 일원 배치분산분석을 실시하였다. 그 결과, VP2에서 집단 간 차이는 통 계적으로 유의하였으나 $\left(F_{(1,32)}=4.411, p<.05\right), \mathrm{NP} 1\left(F_{(1,31)}=2.584\right.$, 
$p=.101), \mathrm{NP} 2\left(F_{(1,31)}=.054, p=.817\right)$ 및 VP1 $\left(F_{(1,31)}=.825, p=.371\right)$ 에서 그룹 간 차이가 유의하지 않았다. 즉, 유의한 이차상호작용은 VP2 구간에서 노년층의 시선고정 비율이 청년층에 비해 낮아지는 것에 기인한다.

\section{논의 및 결론}

노화에 따른 언어처리 능력 감소는 다양한 연구에서 진행되고 있다. 본 연구는 의문사 중에서도 주어와 목적어 처리를 가능하게 하는 누구(who) 의문사를 이용하여 노년층과 청년층의 문장처리 를 비교하고자 하였다. 누구(who) 의문사의 격조사 유형에 따른 집 단 간 과제 수행력 차이와 그 과정에서 나타나는 안구 움직임을 분 석하였다. 본 연구의 목표는 다음과 같다. (1) 문장처리과제에서 누 구(who) 의문사의 격조사 유형에 따라 두 집단 간 정반응률 차이가 있는지 알아보고자 하였다. (2) 문장처리과제에서 누구(who) 의문 사의 격조사 유형에 따라 두 집단 간 목표자극에 대한 총 시선고정 시간 차이가 있는지 알아보고자 하였다. (3) 문장처리과제에서 누 구(who) 의문사의 격조사 유형 별 구간에 따라 두 집단 간 목표자 극의 시선고정비율의 차이가 있는지 알아보고자 하였다.

본 연구결과를 정리하면 다음과 같다. 문장처리과제에서 누구 (who) 의문사의 격조사 유형에 따라 두 집단 간 정반응률 차이를 분석하였다. 그 결과, 노년층 집단의 정반응률은 평균 $84.07 \%$ 이며 청년층 집단의 평균 $97.22 \%$ 에 비해 유의하게 낮은 것으로 나타났 다. 또한, 모든 대상자들이 '누구+를' 유형에서 보다 '누구+가' 유형 에서 높은 정반응률을 보였다. 마지막으로, 집단과 유형에 대한 이 차상호작용이 통계적으로 유의하였다. 즉, '누구+를' 유형에서 집단 간 차이가 '누구+가' 유형에서 집단 간 차이에 비해 유의하게 큰 것 으로 나타났는데, 이는 '누구+를' 유형에서 노년층의 수행력이 저 하되는 것에 기인한다. 본 연구결과는 노년층이 목격적 처리에서 청 년층에 비해 낮은 수행력을 보이는 선행연구(Stine-Morrow, Ryan \& Lenard, 2000) 결과와 일치한다. 이를 통해 노년층이 목적격처리 에서 주격처리에 비해 어려움을 보이는 것을 다시 한번 확인할 수 있다. 또한, heat map을 통해 나타난 노년층의 시선 분산을 고려해 볼 때, 목적격 처리가 주격처리에 비해 더 복잡한 과정임을 시사하 는 선행연구(Neuhaus, \& Penke, 2008; Park \& Choi, 2011)와 같은 맥락으로 해석할 수 있다. 그런데, 노년층 및 청년층에게 동일한 과 제를 제시했음에도 노년층이 청년층에 비해 문법적으로 더 많은 오류를 보이는 것은 노년층의 낮은 인지능력 및 작업기억에 기인하 는 것으로 유추할 수 있고, 이는 선행연구 결과와 일치한다(Caplan et al., 2011; Kemper et al., 2001; Stine-Morrow et al., 2000). 따라서
노년층의 경우 처리용량이 증가되는 복잡한 문장에서 청년층에 비 해 높은 오류를 보인다. 노년층은 특히, 비규범어순(non-canonical) 에서 규범어순(canonical)에 비해 어려움을 보이는 것으로 알려져 있는데(Sung, 2015a), 이것 역시 비규범 어순에서 문장처리가 더 어 렵기 때문이다. 본 연구의 과제 유형 중 ‘누구+를' 유형의 질문을 살 펴보면, 비규범 어순임과 동시에 목적격처리가 함께 들어있는 과제 이다. 즉, 노년층이 어려움을 보이는 것으로 알려진 비규범 어순과 목적격처리가 모두 들어있기 때문에, 노년층은 통사적으로 많은 처 리 부담을 느꼈을 것이고 따라서 청년층에 비해 저하된 수행력을 보인 것으로 해석할 수 있다.

문장처리과제에서 누구(who) 의문사의 격조사 유형에 따라 두 집단 간 목표 자극에 대한 시선고정시간에 차이가 있는지 분석하 였다. 그 결과, 노년층 집단의 평균 $922.75 \mathrm{~ms}$ 와 청년층 집단의 평균 $845.771 \mathrm{~ms}$ 가 통계적으로 유의한 차이가 나타나지 않았다. 비록, 시선고정시간에 있어서 집단 간 차이가 통계적으로 유의하지 않았 으나, heat map에서 노년층의 시선이 청년층에 비해 더 분산되어 있음을 확인할 수 있었다. 시선고정시간과 heat map을 통한 분석 을 종합해 볼 때, 노년층의 질문을 듣고 목표 그림을 고르는 문장처 리 과정이 청년층에 비해 원활하지 못함을 의미한다. 즉, 청년층의 경우 전략적으로 목표자극을 보는 반면, 노년층은 언어처리의 어 려움으로 인해 목표자극을 효율적으로 찾지 못하여 여러 자극(그 림)을 번갈아 본 것으로 나타난다. 따라서 노년층의 시선 이동이 잦 았으며 heat map에서는 흩어진 점들로 확인할 수 있다. 이미 언급 된 바와 같이, 시선추적을 통한 안구 움직임은 지각 및 인지활동을 반영하고(Hyönä et al., 2002; Rayner, 1998; Trueswell \& Gleitman, 2007), 특히 언어적으로는 음운, 의미, 통사, 읽기처리 등의 언어처 리 과정을 살펴보기 위한 도구로 사용되어왔으며 다양한 시선추적 연구에서 시각자료를 활용하여 연구를 진행하여 왔다(Arnold,

Eisenband, Brown-Schmidt, \& Trueswell, 2000; Brandt-Kobele \& Höhle, 2010; Choi, 2019; Hwang, 2019; Wonnaccot, Newport, \& Tranenhaus, 2008). 본 연구에서도 안구움직임을 통해 청년층과 노 년층의 언어처리과정에서 차이를 알아볼 수 있었다. 다음으로, 두 그룹 모두 ‘누구+가' 유형에서 target에 대한 시선고정시간이 길게 나타났다. 이것은, '누구+가' 유형에서 목표 그림(target)을 찾는 처 리 과정이 원활히 일어나는 것으로 해석할 수 있고, heat map에서 그 경향을 확인할 수 있다. "누구+가' 유형의 heat map에서 전반적 으로 목표 그림에 시선이 집중되어 있는 것을 볼 수 있다. 반대로, '누구+를' 유형의 heat map에서는 시선이 목표그림 외에도 여러 그 림으로 분산된 경향을 확인할 수 있고, 이 경향은 노년층에서 더 강 하게 나타난다. 즉, 노년층은 ‘누구+를' 유형에서 강한 시선 분산을 
보였고, 이것은 처리 과정에서 안구 움직임이 자주 이동하였다는 것을 의미한다. 따라서, '누구+를' 유형에서 노년층은 문장처리의 어려움을 느꼈고, 노년층의 복잡한 문장처리 과정이 시선분석으로 제시된 것으로 해석할 수 있다. 마지막으로, '누구+가' 유형에서의 그룹 간 차이와 ‘누구+를' 유형에서의 그룹 간 차이가 유의하지 않 았다. 이것은 그룹 내에서도 개인 간 차이가 크기 때문임을 추측할 수 있다. 청년층 집단과 노년층 집단 모두 표준편차가 매우 큰 편이 다. 집단 내에서도 표준편차가 큰 것에 대한 원인 중 하나로, 개인차 를 꼽을 수 있다. 실험이 끝난 후 인터뷰를 통한 대상자들의 반응을 종합하면, 먼저 그림체에 대한 개인 선호도 차이가 존재했다. 즉, 그 림이 특이하거나 신기해서 더 오래 본 문항이 있다고 대답하였다. 둘째, 과제 수행에 있어 개인의 전략 차이가 있다. 예측 가능한 문제 에서는 질문을 듣고 처리하는 과정이 비교적 짧기 때문에 그림을 오래 보지 않거나 $\mathrm{AOI}$ 이외에 다른 영역을 보는 경우가 있다고 대 답하였다. 이러한 개인차가 있음을 미뤄볼 때, 개인차로 인한 분산 이 높게 나온 것에 기인하여 유형과 집단 간 이차상호작용이 유의 하지 않은 것으로 설명할 수 있다.

문장처리과제에서 '누구+가' 유형의 구간에 따라 두 집단 간 목 표자극에 대한 시선고정비율의 차이가 있는지 분석하였다. 그 결 과, 집단 간 시선고정비율 차이가 없었고 구간 별 평균의 차이도 유 의하지 않았다. 마지막으로, 구간 별 집단 차이 또한 유의하지 않았 다. 이를 종합하면, '누구+가' 유형에서 구간에 따른 집단 간 차이는 유의하지 않는다는 것을 확인할 수 있다. '누구+가' 유형에서 노년 층의 수행력이 청년층과 비교하였을 때 크게 다르지 않았는데, 이 것은 본 연구의 연구 질문 1 번의 결과와도 같은 맥락이다. 즉, "누구 +가' 유형은 규범어순이며 주격조사 처리 수행을 확인하는 쉬운 과 제이기 때문에 집단차이가 나타나지 않은 것을 의미한다.

문장처리과제에서 '누구+를' 유형의 구간에 따라 두 집단 간 목 표자극에 대한 시선고정비율의 차이가 있는지 분석하였다. 그 결 과, 집단 차이가 유의하지 않았으나 구간별 평균의 차이가 유의하 였다. 즉, 문장 후반부로 갈수록 두 집단의 시선고정비율이 높아지 는 것으로 나타났다. 문장의 후반부인 VP2 구간은 답을 고르기 전 최종적으로 문장처리가 일어나는 구간이다. 다시 말해 의미적, 통 사적 처리를 통합하여 문장을 이해하는 구간으로, 이 구간에서는 처리 과정에서 더 많은 시간이 필요함을 뜻한다. 따라서 구간의 차 이는 처리 과정의 복잡성에 기인하는 것으로 해석할 수 있다. 마지 막으로, 집단과 구간에 대한 이차 상호작용이 유의하였는데, 이는 $\mathrm{VP} 2$ 구간에서 노년층의 시선고정비율이 청년층에 비해 낮아지는 것에 기인한다. VP2 구간은 질문의 마지막 어절이다. 이 구간은 '고 르세요'의 지시가 나오는 구간으로, 답을 고르기 직전의 의사결정 (decision making)을 해야 할 때이다. NP1, NP2, VP1 구간에서 문 장처리를 끝내고 마지막 구간인 VP2에서는 답을 고르기 위해 확정 을 짓는 구간이라고 할 수 있다. VP2 구간에서 청년층의 시선고정 비율이 높아지는 것은 문장끝효과(sentence-final effect)로 설명할 수 있다. 문장끝효과는 문장의 마지막 구간에서 시선고정 시간이 길어지는 현상을 가리킨다(Stowe, Kaan, Sabourin, \& Taylor, 2018). 이것은 또한 문장통합효과(sentence wrap-up effect)로 설명 할 수 있다. 이 용어는 단순히 오랜 시간만을 의미하는 것이 아니라, 문장의 끝부분이 문장처리 증가를 반영하는 부분임을 암시한다. 많은 문헌에서, 문장의 마지막 구간에서 문장 통합과정이 일어난다 고 보고되어왔다(Just \& Carpenter, 1980; Rayner, Kambe, \& Duffy, 2000). 이러한 점을 고려하면, VP2 구간은 문장처리를 마무 리 짓고 인지, 언어적 사고가 통합되는 지점임을 알 수 있다. 그런데 노년층은 VP2 구간에서 별다른 증가를 보이지 않았는데, 이를 통 해 노년층이 청년층에 비해 문장끝효과 및 문장통합효과가 낮게 나타나는 것으로 해석할 수 있다. 그런데, '누구+가' 유형에서는 문 장통합효과가 나타나지 않았다. 이것은 '누구+가' 유형이 문장처리 의 복잡성이 낮아서 처리부담이 덜한 유형이기 때문이다. 반면 '누 구+를' 유형은 그 처리과정이 더 복잡하고 인지, 언어적 부담을 요 구하는 유형이기 때문에 문장통합효과가 더 크게 나타난다고 할 수 있다. 즉, '누구+를' 과제의 마지막 구간인 VP2가 문장통합효과 를 살펴볼 수 있는 구간이라 할 수 있는데, 이 구간에서 노년층의 시 선고정비율이 청년층에 비해 낮게 나타나는 것은, 노년층의 문장 통합과정이 효율적이지 못한 것으로 해석할 수 있다.

본 연구에 대한 통합적 논의를 정리하면 다음과 같다. 본 연구는 시선추적기를 활용하여 누구(who) 의문사의 격조사 유형에 따른 청년층과 노년층의 문장처리과정의 차이를 분석하였다. 과제 수행 력을 나타내는 정반응률에서 집단 간 차이가 유의하였고, 시선추 적 변수 중에서는 시간구간에 따른 목표자극 시선고정비율 차이 가 유의한 것으로 나타났다. 본 연구에서 오프라인 측정으로 사용 한 정반응률은 정반응 및 오반응한 모든 문항을 포함한 것으로 전 체 반응에 따른 정반응 비율에 대한 분석이지만, 시선추적 분석은 오반응 문항을 제외하고 정반응한 문항만을 토대로 한 분석이기 때문에 정반응률과 시선추적 결과가 일치하지 않을 수 있다. 즉, 오 프라인에서 정반응한 문항에서 시선추적을 사용한 온라인 실시간 처리 분석에 따른 결과 양상은 다를 수 있다. 시선추적 데이터는 실 시간 처리과정을 기록 및 분석한 것으로, 종속변수를 무엇으로 하 느냐에 따라 측정치가 달라질 수 있다. 본 연구에서는 시선고정시 간, 시선고정비율 두 가지의 변수를 사용하였고, 노년층이 문장처 리과정에서 시간 흐름에 따른 시선고정비율 변수에서 차이를 보이 
는 것을 확인할 수 있었다. 즉 시선추적을 활용한 실시간 처리기법 을 통해 노년층과 청년층의 문장처리과정이 문장의 후반부에서 차 이가 있다는 것을 발견할 수 있었다. 이를 통해 문장처리과정에서 노년층의 시선 이동 및 시선고정비율이 청년층과 다르다는 것을 확 인하였다. 나아가 목적격 처리문장에서 노년층의 문장통합과정의 효율성이 낮다는 것을 알 수 있었다. 이처럼, 시선추적기를 활용한 연구는 오프라인 과제 수행력 측정만으로는 알 수 없는 실시간 문 장처리과정을 알아볼 수 있다는 점에서 장점을 가진다. 이는 국내 의 노년층을 대상으로 하는 제한적인 시선추적 연구에 기초적 자 료를 기여하는데 의미가 있다. 또한, 본 연구를 통해 밝혀진 노년층 의 문장통합과정의 비효율성을 극복하기 위해 말속도 조절, 문장 의 전형성 난이도 조절, 작업기억용량에 대한 부담을 줄여주는 전 략들을 사용하였을 때 긍정적인 효과를 기대할 수 있는지에 대한 향후 연구가 보다 다양하게 시행될 필요가 있다.

본 연구 방법과 결과를 바탕으로 연구가 가지는 제한점을 제시 하고 후속 연구자를 위한 제언을 하고자 한다. 첫째, 본 연구의 대상 자는 서울 및 인천, 경기 지역에 거주하는 청년층 및 노년층이다. 따 라서 이들의 데이터로 정상 청년층 및 정상 노년층을 일반화하기에 는 다소 한계가 있다. 향후 문장처리과제에 관한 연구가 지속적으 로 진행되기 위해서는 지역을 다양하게 모집하고 대상자의 수를 충 분히 하여 통계적 타당도를 높여야 할 것이다. 둘째, 시선고정시간 및 시선고정비율 분석 시, 본 연구에서는 오반응한 문항을 제외하 고 정반응 문항만을 분석하였다. 또한, 시선비율 $30 \%$ 이하는 대상 에서 제외하였다. 이에 따라 분석에서 제외되는 대상자 및 문항이 발생하였다. 따라서 후속 연구에서는 문항과 대상자 수를 충분히 확보하여 데이터의 양적, 질적 측면을 모두 만족하는 통계분석을 할 것을 제안한다.

\section{REFERENCES}

Arnold, J. E., Eisenband, J. G., Brown-Schmidt, S., \& Trueswell, J. C. (2000). The rapid use of gender information: evidence of the time course of pronoun resolution from eye tracking. Cognition, 76(1), B13-B26.

Ashby, J., Rayner, K., \& Clifton, C. (2005). Eye movements of highly skilled and average readers: differential effects of frequency and predictability. The Quarterly Journal of Experimental Psychology, 58(6), 1065-1086.

Brandt-Kobele, O. C., \& Höhle, B. (2010). What asymmetries within comprehension reveal about asymmetries between comprehension and production: the case of verb inflection in language acquisition. Lingua, 120(8), 1910-1925.
Caplan, D., Dede, G., Waters, G., Michaud, J., \& Tripodis, Y. (2011). Effects of age, speed of processing, and working memory comprehension of sentences with relative clauses. Psychology and Aging, 26(2), 439-450.

Chang, S. (1998). The study of the actual usage of the Korean wh-words. Korean Journal of Linguistics, 23(4), 691-708.

Choi, S. K. (2019). Age-related decline in storage and processing components of working memory: an eye-tracking study. Communication Science \& Disorders, 24(1), 205-219.

Christensen, K. J., Multhaup, K. S., Nordstrom, S., \& Voss, K. (1991). A cognitive battery for dementia: development and measurement characteristics. Psychological Assessment: A Journal of Consulting and Clinical Psychology, 3(2), 168-174.

Dickey, M. W., Choy, J. J., \& Thompson, C. K. (2007). Real-time comprehension of wh-movement in aphasia: evidence from eyetracking while listening. Brain and Language, 100(1), 1-22.

Dickey, M. W. \& Thompson, C. K. (2009). Automatic processing of wh-and NP movement in agrammatic aphasia: evidence from eyetracking. Journal of Neurolinguistics, 22(6), 563-583.

Han, S. H. (2000). Modern Korean intransitive verb study. Seoul: Hankookmunhwasa.

Henderson, J. M., \& Pierce, G. L. (2008). Eye movements during scene viewing: evidence for mixed control of fixation durations. Psychonomic Bulletin \& Review, 15(3), 566-573.

Holmqvist, K., Nyström, M., Andersson, R., Dewhurst, R., Jarodzka, H., \& Van de Weijer, J. (2011). Eye tracking: a comprehensive guide to methods and measures. OUP Oxford.

Hutzler, F., \& Wimmer, H. (2004). Eye movement of dyslexic children when reading in a regular orthography. Brain and Language, 89(1), 235-242.

Hwang, S. H. (2019). Age-related differences in the predictable of verb-thematic roles: an eye-tracking study. Communication Science \& Disorders, 24(3), 447-459.

Hyönä, J., Lorch Jr, R. F., \& Kaakinen, J. K. (2002). Individual differences in reading to summarize expository text: evidence from eye fixation patterns. Journal of Educational Psychology, 94(1), 44-55.

Jo, H. L. (2019). Age-related difference in word recognition task according to the interference types: evidence from eye-tracking. Communication Science \& Disorders, 24(1), 186-204.

Just, M. A., \& Carpenter, P. A. (1980) .A theory of reading: from eye fixations to comprehension. Psychological Review, 87(4), 329-354.

Just, M. A., \& Carpenter, P. A. (1992). A capacity theory of comprehension: 
individual differences in working memory. Psychological Review, 99(1), 122-149.

Kang, Y. W. (2006). A normative study of the Korean-Mini Mental State Examination (K-MMSE) in the elderly. Journal of Korean Psychology, 25(2), 1-12.

Kang, Y. W., \& Na, D. L. (2003). Seoul Neuropsychological Screening Battery. Incheon: Human Brain Research \& Consulting Co.

Kemper, S., \& Kemtes, K. A. (1999). Limitations on syntactic processing. In S. Kemper \& R. Kliegl (Eds.), Constraints on language: aging, memory, and grammar (79-106). New York: Kluwer Academic.

Kemper, S., Thompson, M., \& Marquis, J. (2001). Longitudinal change in language production: effects of aging and dementia on grammatical complexity and propositional content. Psychology and Aging, 16(4), 600-614.

Kim, B. J., \& Oh, S. (2013). Age-related changes in cognition and speech perception. Korean Journal of Audiology, 17(2), 54-58.

Kim, S. C. (1997). Syntax development. New language life, 7(1), 125-142.

Kwon, M. S., Kim, H. H., Choi, S. S., Na, D. L., \& Lee, K. H. (1998). A study for analyzing spontaneous speech of Korean adults with CIU scoring system. Korean Journal of Communication \& Disorders, 3, 35-49.

Lee, E. K., \& Kwon, D. H. (1999). A study on the development of case morphemes in normal children aged from two to four years who live in Taegu. Journal of Speech \& Hearing Disorders, 8(2), 131-153.

Lee, J., Kim, D. J., \& Park, H. (2019). Native listeners' evaluations of pleasantness, foreign accent, comprehensibility, and fluency in the speech of accented talkers. Proceedings of the 10th Annual Pronunciation in Second Language Learning and Teaching Conference. 168-178.

Lee, K. M. (2004). Donga-Saegugeo-Sajeon 5th ed. Seoul: Doosan Donga Corporation.

Lee, Y. J., Lee, J. S., \& Lee, J. U. (1997). The semantic-syntactic development in one, two and three year-olds: a focus on the development of partides, compound and complex sentences. International Journal of Early Childhood Education, 17(2), 55-75.

National Institute of Korean Language. (2010). Pyojun-Gugeo-Daesajeon. Seoul: National Institute of Korean Language.

Neuhaus, E., \& Penke, M. (2008). Production and comprehension of wh-questions in German Broca's aphasia. Journal of Neurolinguistics, 21(2), 150-176.

Pae, S. Y. (1997). Study on the acquisition of grammatical morphemes of Korean children: case marker ka, i, neun, do, leul. Communication Sciences \& Disorders, 15(2), 55-74.

Park, J. E., \& Choi, Y. L. (2011). Comprehension of Wh-questions in Broca's aphasia. Journal of Rehabilitation Research, 15(2). 55-74.

Rayner, K. (1998). Eye movements in reading and information processing: 20 years of research. Psychological Bulletin, 124(3), 372-422.

Rayner, K. (2009). Eye movements and attention in reading, scene perception, and visual search. The Quarterly Journal of Experimental Psychology, 62(8), 1457-1506.

Rayner, K., Kambe, G., \& Duffy, S. A. (2000). The effect of clause wrap-up on eye movements during reading. The Quarterly Journal of Experimental Psychology, 53A(4), 1061-1080.

Seo, S. K. (1998). Investigation of word frequency based on corpus analysis and its application-Yonsei corpus. Han-geul, 242, 225-270.

Shin, M. J., \& Han, S. J. (2003). A study of speech rate and fluency in normal speakers. Korean Journal of Speech Science, 10(2), 159-168.

Sohn, H. M. (Ed.). (2006). Korean language in culture and society. Honolulu, HI: University of Hawaii Press.

Spit, S., \& Rispens, J. (2019). On the relation between procedural learning and syntactic proficiency in gifted children. Journal of Psycholinguistic, 48(2), 417-429.

Stine-Morrow, E. A. L., Ryan, S., \& Leonard, J. S. (2000). Age differences in on-line syntactic processing. Experimental Aging Research, 26(4), 315-322.

Stowe, L. A., Kann, E., Sabourin, L., \& Taylor, R. C. (2018). The sentence wrapup dogma. Cognition, 176, 232-24

Sung, J. E. (2015a). Effect of syntactic structure on sentence comprehension ability as a function of the canonicity of word-order and its relation to working memory capacity on Korean-speaking elderly adults. Communication Science \& Disorders, 20(1), 24-33.

Sung, J. E. (2015b). Age-related changes in sentence production abilities and their relation to working-memory capacity: evidence from a verb-final language. PLoS One, 10(4), e0119424

Sung, J. E. (2017). Age-related decline in case-marker processing and its relation to working memory capacity. The Journals of Gerontology Series B: Psychological Sciences and Social Sciences, 72(5), 813-820.

Sung, J. E., Yoo, J. K., Lee, S. E., \& Eom, B. (2017). Effects of age, working memory, and word order on passive-sentence comprehension: evidence from a verb-final language. International Psychogeriatrics, 29(6), 939-948.

Thornton, R., \& Light, L. L. (2006). Language comprehension and production in normal aging. In J. E. Birren \& K. W. Schaie (Eds.), Handbook of the psychology of aging (6th ed.) (pp. 261-287). San Diego, CA: Academic Press.

Trueswell, J. C., \& Gleitman, L. R. (2007). Learning to parse and its implications for language acquisition. In G. Gaskell (ed.). The Oxford handbook of 
psycholinguistics (pp. 635-656). Oxford, UK: Oxford University Press.

Tyack, D., \& Ingram, D. (1977). Children's production and comprehension of questions. Journal of Child Language, 4(2), 211-224.

Wonnacott, E., Newport, E. L., \& Tanenhaus, M. K. (2008). Acquiring and processing verb argument structure: distributional learning in a miniature language. Cognitive Psychology, 56(3), 165-209.

Yoon, B. N. \& Kim, C. S. (2008). The Types of Multiple Wh-Questions and Superiority Condition. The Linguistic Association of Korea Journal, 16(4), 63-85. 
Appendix 1. 과제 유형별 자극목록

\begin{tabular}{|c|c|}
\hline \multicolumn{2}{|r|}{ ‘누구+가' 유형 } \\
\hline 1 & $\begin{array}{l}\text { 어느날, 말과 양이 들에 있었습니다. 말이 양을 물었습니다. 쥐가 엎드렸습니다. } \\
\text { 지금, 누가 양을 물었는지 고르세요. }\end{array}$ \\
\hline 2 & $\begin{array}{l}\text { 어느날, 귀신과 마녀가 별장에 있었습니다. 귀신이 마녀를 따라갔습니다. 수녀가 들어왔습니다. } \\
\text { 지금, 누가 마녀를 따라갔는지 고르세요. }\end{array}$ \\
\hline 3 & $\begin{array}{l}\text { 어느날, 젖소와 사슴이 농장에 있었습니다. 젖소가 사슴을 막았습니다. 거미가 놀랐습니다. } \\
\text { 지금, 누가 사슴을 막았는지 고르세요. }\end{array}$ \\
\hline 4 & $\begin{array}{l}\text { 어느날, 시녀와 왕비가 궁전에 있었습니다. 시녀가 왕비를 불렀습니다. 무사가 뛰어갔습니다. } \\
\text { 지금, 누가 왕비를 불렀는지 고르세요. }\end{array}$ \\
\hline 5 & $\begin{array}{l}\text { 어느날, 판사와 군인이 병원에 있었습니다. 판사가 군인을 도왔습니다. 의사가 웃었습니다. } \\
\text { 지금, 누가 군인을 도왔는지 고르세요. }\end{array}$ \\
\hline 6 & $\begin{array}{l}\text { 어느날, 아내와 남편이 슈퍼에 있었습니다. 아내가 남편을 꼬집었습니다. 점원이 당황했습니다. } \\
\text { 지금, 누가 남편을 꼬집었는지 고르세요. }\end{array}$ \\
\hline 7 & $\begin{array}{l}\text { 어느날, 토끼와 염소가 동굴에 있었습니다. 토끼가 염소를 괴롭혔습니다. 개미가 달아났습니다. } \\
\text { 지금, 누가 염소를 괴롭혔는지 고르세요. }\end{array}$ \\
\hline 8 & $\begin{array}{l}\text { 어느날, 돼지와 거위가 우리에 있었습니다. 돼지가 거위를 쫓아냈습니다. 늑대가 서성였습니다. } \\
\text { 지금, 누가 거위를 쫓아냈는지 고르세요. }\end{array}$ \\
\hline 9 & $\begin{array}{l}\text { 어느날, 햄스터와 고양이가 식물원에 있었습니다. 햄스터가 고양이를 쫓아갔습니다. 앵무새가 날아갔습니다. } \\
\text { 지금, 누가 고양이를 쫓아갔는지 고르세요. }\end{array}$ \\
\hline 10 & $\begin{array}{l}\text { 어느날, 고릴라와 코끼리가 동물원에 있었습니다. 고릴라가 코끼리를 찼습니다. 얼룩말이 물러섰습니다. } \\
\text { 지금, 누가 코끼리를 찼는지 고르세요. }\end{array}$ \\
\hline 11 & $\begin{array}{l}\text { 어느날, 개구리와 사마귀가 논두렁에 있었습니다. 개구리가 사마귀를 눌렀습니다. 도마뱀이 비켰습니다. } \\
\text { 지금, 누가 사마귀를 눌렀는지 고르세요. }\end{array}$ \\
\hline 12 & $\begin{array}{l}\text { 어느날, 다람쥐와 지렁이가 놀이터에 있었습니다. 다람쥐가 지렁이를 흔들었습니다. 까마귀가 지저귀었습니다. } \\
\text { 지금, 누가 지렁이를 흔들었는지 고르세요. }\end{array}$ \\
\hline \multicolumn{2}{|r|}{ '누구+를’ 유형 } \\
\hline 1 & $\begin{array}{l}\text { 어느날, 닭과 벌이 숲에 있었습니다. 닭이 벌을 피했습니다. 곰이 지나갔습니다. } \\
\text { 지금, 누구를 닭이 피했는지 고르세요 }\end{array}$ \\
\hline 2 & $\begin{array}{l}\text { 어느날, 꽃게와 소라가 바위에 있었습니다. 꽃게가 소라를 잡았습니다. 악어가 깔깔거렸습니다. } \\
\text { 지금, 누구를 꽃게가 잡았는지 고르세요 }\end{array}$ \\
\hline 3 & $\begin{array}{l}\text { 어느날, 고래와 새우가 바다에 있었습니다. 고래가 새우를 기다렸습니다. 문어가 떠났습니다. } \\
\text { 지금, 누구를 고래가 기다렸는지 고르세요 }\end{array}$ \\
\hline 4 & $\begin{array}{l}\text { 어느날, 가수와 모델이 카페에 있었습니다. 가수가 모델을 그렸습니다. 화가가 떠들었습니다. } \\
\text { 지금, 누구를 가수가 그렸는지 고르세요 }\end{array}$ \\
\hline 5 & $\begin{array}{l}\text { 어느날, 학생과 무당이 극장에 있었습니다. 학생이 무당을 보았습니다. 아기가 울었습니다. } \\
\text { 지금, 누구를 학생이 보았는지 고르세요 }\end{array}$ \\
\hline 6 & $\begin{array}{l}\text { 어느날, 복어와 조개가 어항에 있었습니다. 복어가 조개를 밀었습니다. 해마가 까불었습니다. } \\
\text { 지금, 누구를 복어가 밀었는지 고르세요 }\end{array}$ \\
\hline 7 & $\begin{array}{l}\text { 어느날, 낙타와 여우가 사막에 있었습니다. 낙타가 여우를 깨물었습니다. 전갈이 자빠졌습니다. } \\
\text { 지금, 누구를 낙타가 깨물었는지 고르세요 }\end{array}$ \\
\hline 8 & $\begin{array}{l}\text { 어느날, 요리사와 소방관이 비행기에 있었습니다. 요리사가 소방관을 건드렸습니다. 경호원이 하품했습니다. } \\
\text { 지금, 누구를 요리사가 건드렸는지 고르세요 }\end{array}$ \\
\hline 9 & $\begin{array}{l}\text { 어느날, 여학생과 남학생이 축구장에 있었습니다. 여학생이 남학생을 놀렸습니다. 선생님이 돌아다녔습니다. } \\
\text { 지금, 누구를 여학생이 놀렸는지 고르세요 }\end{array}$ \\
\hline 10 & $\begin{array}{l}\text { 어느날, 독수리와 거북이가 해안가에 있었습니다. 독수리가 거북이를 쪼았습니다. 너구리가 얼씬거렸습니다. } \\
\text { 지금, 누구를 독수리가 쪼았는지 고르세요 }\end{array}$ \\
\hline 11 & $\begin{array}{l}\text { 어느날, 원숭이와 잠자리가 분수대에 있었습니다. 원숭이가 잠자리를 찔렀습니다. 강아지가 짖었습니다. } \\
\text { 지금, 누구를 원숭이가 찔렀는지 고르세요 }\end{array}$ \\
\hline 12 & $\begin{array}{l}\text { 어느날, 승무원과 간호사가 화장실에 있었습니다. 승무원이 간호사를 당겼습니다. 청소부가 서 있었습니다. } \\
\text { 지금, 누구를 승무원이 당겼는지 고르세요 }\end{array}$ \\
\hline
\end{tabular}

Appendix 2. 과제 유형별 질문 예시

\begin{tabular}{lcccc}
\hline 질문 유형 & NP1 & NP2 & VP1 & VP2 \\
\hline '누구+가' & 누가 & 지렁이를 & 흔들었는지 & 고르세요 \\
'누구+를' & 누구를 & 다람쥐가 & 흔들었는지 & 고르세요 \\
\hline
\end{tabular}




\section{국문초록}

\section{시선추적을 활용한 청년층 및 노년층의 누구(who) 의문사처리 연구 장지혜 · 성지은 \\ 이화여자대학교 언어병리학과}

배경 및 목적: 본 연구에서는 청년층과 노년층의 문장처리과제 수행력과 시선추적 데이터를 비교하고자 하였다. 방법: 청년층 21 명과 정상노년층 17 명이 본 실험에 참가하였다. 모든 대상자는 선별검사에서 인지 및 언어검사를 통과하였고 집단 간 교육연수에서 차이가 없었다. 본 연구에서는 누구(who) 의문사에 결합하는 격조사를 주격조사(-가)와 목적격조사(-를) 두가지를 사용하여 문장처리과제를 두개의 유형으로 나눠 실험을 진행하였다. 대상자들은 화면에 제시되는 그림을 보며 이야기 및 질문을 들은 후 그에 맞는 답을 키보드 로 눌렀고, 그 과정에서 시선추적 데이터가 기록되었다. 결과: 과제수행에 있어서 정반응률에 대한 집단 차이가 유의하였다. 노년층이 ‘누구+를' 유형에서 훨씬 낮은 수행력을 보였다. 다음으로 목표자극에 대한 총 시선고정시간에서 집단 간 차이는 유의하지 않았으나 모 든 집단이 ‘누구+를' 유형에서 시선고정시간이 짧았고, heat map을 통해서 노년층의 시선이 청년층에 비해 분산됨을 확인할 수 있었다. 또한, 시간구간에 따른 목표자극 시선고정비율에서 노년층이 문장의 마지막 구간에서 시선고정비율이 낮아짐을 보였다. 논의 및 결 론: 노년층이 청년층에 비해 ‘누구+를’ 유형에서 정반응률이 낮고 시선의 분산 정도가 강하게 나타났다. 나아가 문장의 마지막 구간에 서 노년층의 시선고정비율 감소를 통해 노년층이 청년층에 비해 문장통합과정의 효율성이 저하됨을 추측할 수 있었다. 이러한 연구결 과는 국내의 노년층을 대상으로 하는 문장처리연구에 기여하는데 의의가 있다.

핵심어: 노년층 문장처리, 시선추적연구, 의문사, 격조사

본 논문은 대한민국 교욱부와 한국연구재단의 지원을 받아수행된 연구임(NRF-2019R1A2C1089280).

\section{참고문헌}

강연욱(2006). K-MMSE (Korean version of Mini-Mental State Exam)의 노인 규준 연구. 한국심리학회지: 일반, 25(2), 1-12.

강연욱, 나덕렬(2003). 서울신경심리검사(SNSB). 인천: Human Brain Research \& Consulting Co.

국립국어원(2010). 표준국어대사전. 서울: 국립국어원.

권미선, 김향희, 최상숙, 나덕렬, 이광호(1998). 한국 성인의 자발화분석에 관한 연구: CIU분석법을 중심으로. 언어청각장애연구, 3, 35-49.

김성찬(1997). 통사규칙 발달. 새국어생활, 7(1), 125-142.

박정은, 최예린(2011). 브로카 실어증 환자의 의문문이해. 재활복지, 15(2). 55-74.

배소영(1997). 한국아동의 문법 형태소 습득 연구: 조사가, 이, 는, 도, 를 언어청각장애연구, 2, 27-42.

서상규(1988). 말뭉치 분석에 기반을 둔 낱말 빈도의 조사와 그 응용- '연세말뭉치를 중심으로. 한글, 242, 225-270.

성지은(2015a). 한국어 어순 규범성과 문장유형이 노년층 문장이해능력에 미치는 영향 및 작업기억용량과의 관계. Communication Science \& Dis-

orders, 20(1), 24-33.

신문자, 한숙자(2003). 정상 성인의 말속도 및 유창성 연구. 음성과학, 10(2), 159-168.

윤병노, 김창수(2008). 다중의문사 의문문의 유형과 우위조건. 언어학, 16(4), 63-85.

이기문(2004). 동아새국어사전 5판. 서울: 두산동아.

이순형(2000). 한국 아동이 초기에 획득한 문법적 형태소의 종류 및 획득시기. 아동학회지, 21(4), 51-68.

이순형(1983). 한국 아동의 언어 획득에 관한 연구II. 덕성여대 논문집, 12, 183-203.

이영자, 이종숙, 이정욱(1997). 1, 2, 4세 유아의 의미-통사적 발달 연구: 문법 범주 및 문장유형의 발달을 중심으로. 유아교육연구, 17(2), 55-75.

이은경, 권도하(1999). 2-4세 유아의 격조사발달에 관한 연구. 언어치료연구, 8(2), 131-153. 
장소원(1988). 국어 의문사 어휘의 실제적 용법 연구. 언어학, 23(4), 691-708.

조혜련(2019). 시선추적을 활용한 방해자극 유형에 따른 단어재인과제에서 청년층과 노년층 간 수행력 비교. Communication Science \& Disorders, 24(1), 186-204.

최서경(2019). 시선추적을 활용한 청년층과 노년층의 작업기억의 저장 및 처리기능 연구. Communication Science \& Disorders, 24(1), 205-219. 한송화(2000). 현대 국어 자동사 연구. 서울: 한국문화사.

황상흠(2019). 시선추적을 활용한 동사의 의미역 예측 정도가 노년층 의미역 처리에 미치는 영향. Communication Science \& Disorders, 24(2), 447-

459.

\section{ORCID}

장지혜(제1저자, 대학원생 https://orcid.org/0000-0002-5011-7341); 성지은(교신저자, 교수 https://orcid.org/0000-0002-1734-0058) 